\title{
Determination of University Students' Solutions to Climate Change through PESTEL Analysis in The Sample of Ataturk University
}

\section{Aslıhan Esringü ${ }^{1} *$ iD, Süleyman TOY $^{2}$}

${ }^{1}$ Atatürk University Architecture and Design Faculty, Landscape Architecture Department Erzurum, Turkey, ${ }^{2}$ Atatürk University Architecture and Design Faculty City and Regional Planning Department, Erzurum, Turkey

Geliş / Received: 30/11/2021, Kabul / Accepted: 16/12/2021

\begin{abstract}
Climate change is an important problem for the world since it causes serious impacts on humans. Action to take measures is to raise awareness among people using innovative methods. PESTEL is an effective environmental analysis method used in planning for businesses. Present study uses this analysis to determine youth's opinions about the solutions to the problems caused by climate change. The study adopts three - staged application including one conference, training and workshop using PESTEL analysis over 60 university students from the academic departments related to the factors of PESTEL. As the result of the study, students' views on the solution of climate change are categorised into six factor categories, political, urban issues, agricultural problems, energy, economic matters and education. Results also show that the students find political factors, education and urbanisation as the most important three keywords which can solve climate change problem and where measures should be taken.
\end{abstract}

Keywords: Climate change, PESTEL, university youth, awareness

\section{Atatürk Üniversitesi Örneğinde Üniversite Öğrencilerinin PESTEL Analizi ile İklim Değişikliğine Karşı Çözümlerinin Belirlenmesi}

\section{$\ddot{\mathbf{O z}}$}

İklim değişikliği tüm ülkelerin mücadele ettiği küresel bir sorun olduğu bilinmektedir. Bu küresel problem ile mücadele konusunda alınacak tedbirler arasında çevre eğitimleri oldukça önemli görülmektedir. Çevre eğitimleri gelecek nesillerin farkındalık kazanmasında temel bir rol oynamaktadır. Bu amaçla Avrupa Birliği (AB) tarafından finanse edilen bir proje kapsamında hedef kitle olarak Atatürk Üniversitesinin 6 farklı fakültesinden toplam 60 öğrenci seçilmiş ve 3 gün süren eğitimler ile iklim değişikliği konusunda öğrencilerin bilgi ve bilinç düzeylerinde artış sağlanması hedeflenmiştir. Eğitim programının ilk günü iklim değişikliği konusunun uzmanı bir öğretim üyesi tarafından çalışmanın örnekleminde yer alan öğrencilere bir konferans, ikinci günü sadece eğitim programına alınan öğrencilere tüm gün eğitim ve üçüncü gün ise çalıştay programı şeklinde izlenmiştir. Çalıştay kapsamında öğrencilerin PESTEL analizi yöntemiyle iklim değişikliğine çözüm önerileri sunmaları istenmiştir. Sonuç olarak bu tarz eğitimlerin sayılarının artırılarak daha geniş kitlelere ulaşım sağlanarak çevre bilinci oluşmuş çevre dostu, ekolojik ve sosyal sorumlukları artırılmış bireyler ile yeşil bir toplumun oluşturması mümkün olacaktır.

*Corresponding Author: esringua@ hotmail.com 
Anahtar kelimeler: İklim değişikliği, PESTEL, üniversite gençliği, farkındalık

\section{Introduction}

In the years following the Industrial Revolution $(1770-1850)$, the demand for fossil fuels (coal, oil, natural gas, etc.), which were then the only sources to supply energy, increased so rapidly that as a result of this process, it turned out to be a challenge to control the amount of carbon dioxide $\left(\mathrm{CO}_{2}\right)$ emissions which is among the main reasons of global warming. The rates of other naturally existing greenhouse gases $\left(\mathrm{CH}_{4}, \mathrm{NO}, \mathrm{N}_{2} \mathrm{O}, \mathrm{HFCs}, \mathrm{SF}_{6}\right.$ and PFCs) in the atmosphere increased also depending on the anthropogenic activities such as forestry, industrial production and agriculture. In a few decades, increased rate of greenhouse gases caused changes in climate at global or regional scale (Houghton et al., 2001).

The Intergovernmental Panel on Climate Change (IPCC 2001; 2007) defines climate change as "any change in climate over time, whether due to natural variability or as a result of human activity" while the Framework Convention on Climate Change attributes the change of climate directly or indirectly to human activity that alters the composition of the global atmosphere and that is in addition to natural climate variability observed over comparable time periods."

The changes in climate have serious impacts on the sustainability of earth ecosystem and human life thus threatening the existence of both (Ediger 2008). Climate change also worsens social welfare and slows down economic development by affecting negatively the future of the planet (Fankhauser and Tol, 2005). The Fourth Assessment Report (AR4) of IPCC states that in case the level of economic and social welfare declines people with limited economic possibilities are expected to be impacted to a higher degree. It is not possible to launch development goals in the third millennium without a stable climate and knowing the possible future trends of changes. Climate change will aggravate already - hard living conditions of poor people in underdeveloped, unstable and bad - governed countries and eventually lead to violent social conflicts (Smith and Vivekananda, 2007). Environmental, climatic and ecological issues are the sources of growing global concern. In order to solve these problems, it is very important to strengthen the changes of individual lifestyles by eliminating traditional understandings all around the world (Neubauer 2014). Therefore, authorities are required to take related and urgent measures. Within this context, The European Commission developed the European Climate Change Programme (ECCP) based on the policy measures to mitigate the emissions of greenhouse gases the driving force of global warming in every member state (European Commission 2000). Among the sets of measures to be taken against the impacts of climate change, environmental education plays important roles to increase the awareness about the subject (Grace and Ratcliffe 2002). Environmental education may be perceived as a way of reconsidering the relationships between the biosphere and humans and a social transformation tool for sustainable development (Candamio et al, 2018). Therefore; environmental education plays an important role in raising awareness on this issue among children, the youth, parents, instructors, academicians and administrators to the desired level. Environmental education covers the approaches, tools and programs that develop and raise environmental attitudes, values, knowledge and skills that prepare people to take action by giving information to them about environment (Monroe and Krasny,2016). 
Environmental education provides individuals with a specific perspective on how to evaluate various aspects of a subject and improve their decision-making skills by developing critical thinking (Monroe and Krasny 2016. It is also a conservation strategy to increase the number of opportunities to meet scientists, decision makers, community members and other stakeholders for common environmental targets (Toomey et al., 2017). In addition, environmental education can create synergistic research and application points among various stakeholders to enable individuals to develop a deeper understanding of environmental problems and at the same time have the skills to make informed and responsible decisions (Toomeyet et al., 2017, Ardoin et al, 2020).

It is clearly stated when especially considered the roles universities play that educating future professionals, decision makers, entrepreneurs, academics and world leaders is the vitally important mission and the environmental education programs are necessity in these institutions (Guerra et al, 2018). In some previous studies, students are accepted to be the solution proposers for environmental matters (Grady-Benson and Sarathy 2015). It is an expected outcome when official curricula at higher education includes the subjects related to the reduction of global warming emissions and sustainability topics, then students will be able to complete their future social missions for creating an ethical and civil society to struggle with climate change. From this point of view, interdisciplinary thinking in higher education institutions constitutes the goal of sustainable development (Azeiteiro et al., 2015). It was stated in a survey study (Candamio et al, 2018) where the mechanisms behind people's green or pro-environmental behaviour were investigated that environmental education plays a critical role in people's adoption of pro-environmental behaviours (Candamio et al, 2018). It was also stated in another survey study by Meyer (2015) that when individuals in higher educated groups receive environmental education its effects are also greater on people's behaviour. It was also stated by Zsoka et al. (2013) that there is a strong relationship between the environmental education received from universities and the environmental knowledge that students acquire. In this respect, in this study, effects of a short-term education study on climate change are investigated through its follow - up workshop using PESTEL analysis technique to determine the knowledge levels and solution proposals of students for the problems to political, economic, social, technological, legal and environmental aspects. PESTEL analysis is used in strategy development to evaluate the macro-environmental conditions of a subject (or a company) in question to the political, economic, social, technologic, environmental and legal aspects in order to determine negative or positive sides of the interactions to be modelled (Oktay 2006). Totally aforementioned six factors are taken into consideration in the analysis. Adoption of such an environmental analysis methodology as PESTEL can provide the bases for the determination of the advantages, opportunities and threats towards a company or the subject investigated (Yüksel 2012). PESTEL analysis is defined and employed in various ways and names in the previous studies like ETPS (economic, technical, political, and social; Aguilar 1967), PEST (Dare, 2006), STEPE (Richardson, 2006) and PESTEL (Yüksel 2012). Even though it is mostly used in the present situation analyses of strategic planning, PESTEL analysis has been preferred in a range of topics from business to education and tourism (Katko, 2006; Richardson, 2006; Shilei and Yong, 2009; Bakoğlu and Yıldız 2018). 
Determination of University Students' Solutions to Climate Change through PESTEL Analysis in The Sample of Ataturk University

Objective of the present study is to determine the solution proposals of university youths towards climate change using an innovative technique which categorizes them according to political, economic, social, technological, environmental and legal aspects.

\section{Material and Method}

\section{Study Area}

The study was conducted at Atatürk University in Erzurum. The city of Erzurum is located in the east of Turkey at an altitude ranging between $1.850 \mathrm{~m}$ and $2.100 \mathrm{~m}(39.55 \mathrm{~N}$ and $41.16 \mathrm{E}$; TRA1 NUTSII Region; Figure 1), in the city centre with a population of 758.279 (TurkStat 2021). Harsh continental climate characteristics are prevalent in the city. Long-term annual mean temperature is $5.1^{\circ} \mathrm{C}$ (temperature extremes $-37.2^{\circ} \mathrm{C}$ and $35.6^{\circ} \mathrm{C}$ ), rainfall is $413.3 \mathrm{~mm}$ and relative humidity is $63.3 \%$. Prevalent wind directions are ENE in summer and WSW in winter.

Atatürk University, which was established in 1957 in a campus of 300 hectares with 850.000 $\mathrm{m}^{2}$ indoor area takes place among the top 200 universities all over the world in the respect of Quality Education and Life on Land. The University had 398 thousand 943 students in 2019 2020 education term, nearly 80 thousand of whom actively use campus and is the $3^{\text {rd }}$ university in the country for student number. The University has 23 faculties, 1 conservatory, 1 school, 12 vocational schools, 8 institutions, 38 application and research centres, 45 units and 851 programs.

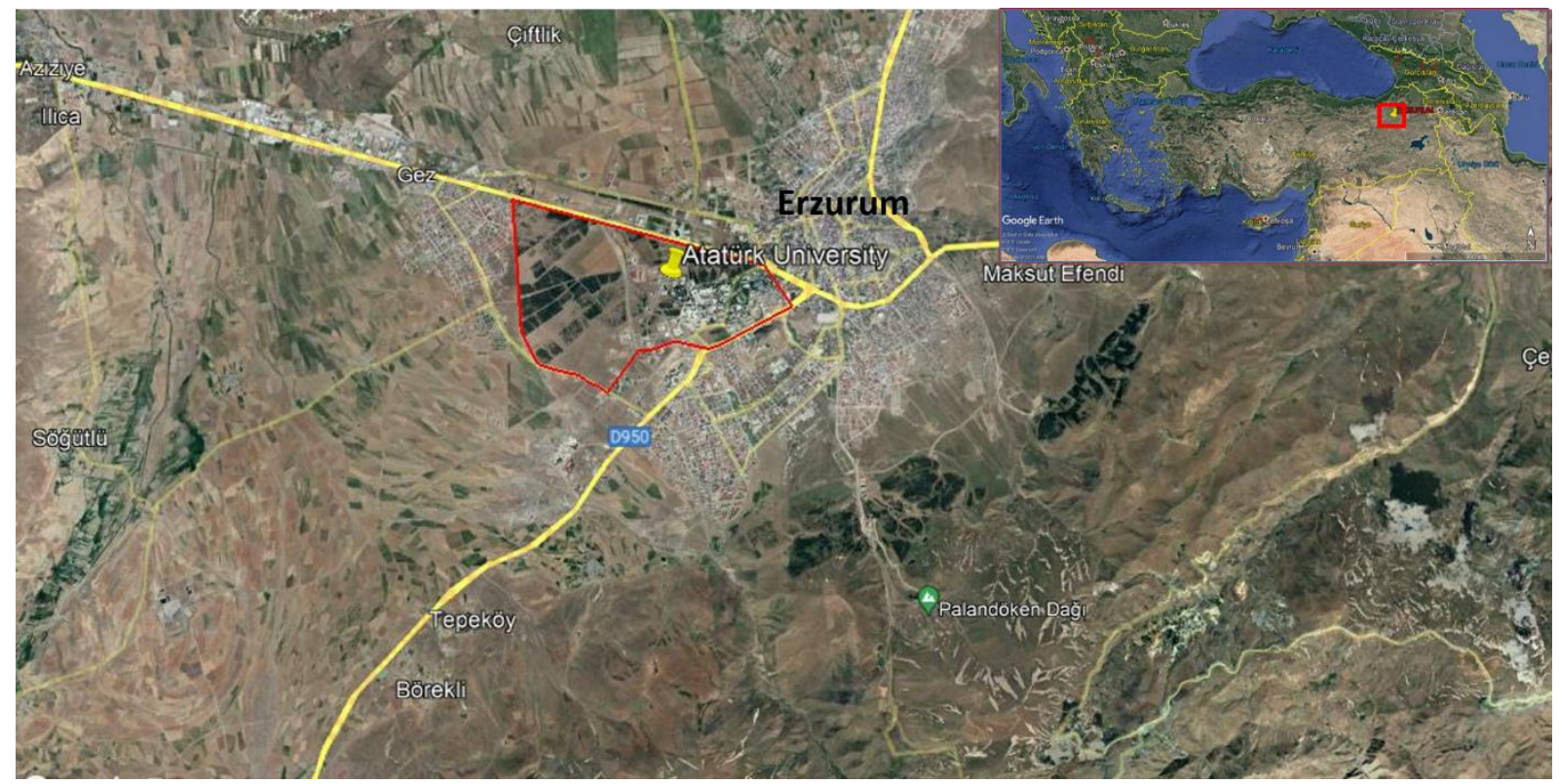

Figure 1. Location of Atatürk University

\section{Study Group}

The study was conducted on 11 - 13 April 2019 in the scope of a EU Project (sub-grant Env.Net supported University Youth is Discussing Climate Change at the peak of Anatolia) main aim of which was to disseminate knowledge about climate change, its cause and results among university youth using an innovative techniques called PESTLE, an analysis 
evaluating present situation of a concept from political, economic, social, technical, legal and environmental points of view. Therefore, the project began with the determination of participant students from the faculties convenient with the PESTLE content, i.e. Faculty of Economics and Administrative Sciences (public administration, economics and management departments) for politics and economics (PE; 20 students), Faculty of Literature (sociology and geography departments; S;10 students), Faculty of Architecture and Design (City and Regional Planning, Architecture and Landscape Architecture Departments; T;10 students), Faculty of Law (L; 10 students) and Faculty of Agriculture and Environmental Engineering Department (E; 10 students). Totally 60 voluntarily participating students were at the 2 nd or 3rd grade and $58.3 \%$ female and $41.7 \%$ male.

Through the trainings at 3 sessions for the participant students in the project, it is aimed for students to be aware of climate change facts, gain insights about the attempts at national and global scales and the measures to be taken in order to develop desired attitudes and behaviors against the present and future environmental problems. The conference, first session of the training was help with the participation of 360 students and teaching staff across the university on the first day. On the second day, the second session of the training was on direct effects of climate change and completed with the participation of the selected students considering the academic units in convenience with the categories of PESTEL factors. Third session of the project was the PESTEL workshop which was held by expert academicians and the same students selected for the training on the second day participated in it.

\section{Method and Data Collection}

After the determination of totally 60 voluntary students, a pre-test questionnaire was prepared and shared with students and wanted them to complete the survey through google survey. After the survey, an informing conference (education about climate change) was organised with the presentation of an international expert on climate change, Prof. Dr. Murat Türkeş and then on the second part of the education went on whole day with participant students at Architecture and Design Faculty. Experts gave information about the present and future situation, thematic and sectoral subjects. After the education program, students were also applied a post-test questionnaire survey to find their knowledge and awareness level after the project.

In the study, the same university students receiving education for raising awareness participated in a workshop next day. In the workshop, 60 students were classified in 6 groups according to their PESTEL category described above to express their opinions in a systematic way (considering PESTEL factors) towards the solutions for the problems caused by climate change. Each group included at least one student from each PESTEL unit and the rest was distributed to the groups selecting randomly. During the workshop participatory approaches were all considered by letting the groups composed of one representatives of PESTEL factors in each group make presentation of their top -5 opinions (sometimes all of them).

Following the training about climate change over two days to the students selected from the 6 academic units (PESTEL themes), a workshop was organised to collect the opinions of students from different disciplines round a table for their solutions to problems caused by climate change based on the insights they gained through training. After collecting the opinions, they were analysed to determine the frequency of opinions given repeatedly by students by scoring the most repeated opinions in a systematic. For instance, if one opinion 
was proposed by 4 different groups then the score of this opinion was accepted to be 4 by giving a score signal " ++++ " in the tables by dividing them into factor categories. Relationship between PESTEL factors and the climate change is explained as follows to express the reason why such a methodology is adopted to evaluate the climate change.

\section{Political Factors}

These factors refer to all outer political decisions or interventions having impacts on a given subject (e.g. adopted national or global policies that are expected to shape the future). As an example from economic / business perspective government policy, political stability or instability in overseas markets, foreign trade policy, tax policy, labour law, environmental law, trade restrictions and so on can be counted among them. political factors often organisations and how they do business. When a political analysis puts the climate change concept at its heart, then regional (if present), national and global decisions are taken into account to evaluate future prospects and impacts. In this respect, it may be useful to state that global environmental matters cause serious hazards to the earth and human life and among them climate change is a very big global problem which can be solved through the efforts from local to international scales and cooperation. Global policies proposed in IPCC's Assessment Reports (AR4 and 5, i.e. mitigation and adaptation) are vitally important for nations and regions to increase their preparedness levels and find solutions to the hazards and vulnerabilities from especially global warming. Therefore, present and future politicians and decision makers should perceive all these critical issues and know how to struggle with them by developing or adopting suitable policies. Based on the expressions above students are expected to produce policy proposals for the impacts of climate change (in)dependent of the existing ones.

\section{Economic Factors}

Economic factors in environmental analysis for a given subject are very important since they include macro and micro-economic indicators like economic growth, employment, prosperity, investments, payment balances, interest rates, exchange rates, inflation, disposable income of consumers and businesses and so on. These factors have impacts on daily life of people and social and economic welfare of nations. When the relationship between climate change and national or global economy is considered it can be stated that all the world nations have to pay an economical cost to mitigate and adapt the climate change in return for the imbalances in especially emerging economies. Nearly no sector is left to be affected by climate change and its dependent impacts like the changes in temperature and rainfall regimes as well as the extremes of every climatic element and meteorological disasters with increasing frequencies like droughts, floods and storms which lead to serious economic losses. Climate change has significant effects on sectoral productivity, employment and growth (Başoğlu 2014). In this respect, from the sides of economic sectors, like industry, agriculture, energy, tourism, both the mitigation and adaptation strategies are prepared and adopted at all scales from local to global. At this point, participant students are expected to produce solutions to decrease climate - related economic losses by looking at the matter from local, national and global perspectives. 


\section{Social Factors}

In the PESTEL analysis methodology the term social includes socio-cultural factors and refers to the common beliefs and attitudes of the society. Among the socio-cultural factors are demographic characteristics like population dynamics, (age and gender distribution, education groups etc.) and others related to socioeconomic ones like dependency ratios (unemployment), consciousness, creativity, innovation and entrepreneurship and many more. Impacts of climate change are seen clearly on social layers of human population all over the world. It is an expected condition that people in less developed and developing countries are in difficulties accessing sufficient economic opportunities to adapt or mitigate the effects of climate change and thus causing social affairs such as public health risks and migrations. Throughout human history nature based social affairs have been witnessed such as large extended and prolonged migrations due to disasters from climate change like floods and droughts (Ekşi (2016). People in disadvantageous groups including the elderly, the poor, women and children are accepted to be more impacted and vulnerable to climate change risks (Demirbilek 2016) such as various health problems, deaths due to heat waves, floods and hurricanes, injuries from extreme weather events, infectious and vector diseases. For the socio - cultural factors, the students are expected to discuss possible results and risks then propose solutions.

\section{Technological Factors}

Rapid development in technology changes also the effective factors on humans and their environment. Therefore, every type of human activity faces new production, distribution and communication methods all over the world with the changing technologies. Climate change is at the heart of technological changes since the negative or positive effects of new technologies are clearly seen on climatic elements and vice versa. Advancement in technology supports the struggle with climate change by easing the mitigation and adaptation efforts. Advanced and high technology help raise awareness level of society about climate change, reduce the size of carbon footprint per nation by supporting research and development programs like The European Strategic Energy Technology Plan- SET, US Climate Change Technology Program CCTP, Cool Earth Innovation Energy Technology Program of Japan and Road to Our Green Future Program of South Korea (Demirtaş 2013). It is vitally important for the society to show interest in innovation activities in order to mitigate and adapt to the impacts of climate change (Su and Moaniba 2017). In addition, new technologies reducing CO2 emissions in the production process is an effective way to mitigate climate change ( $\mathrm{Li}$ and Wang 2017). Students are expected to write down the solutions which include the advantages of new technologies.

\section{Environmental Factors}

Even though these factors are new compared to the others their importance increases based on the heavily consumption of natural resources as raw materials and production of pollution in return for their uses one result of which causes climate change and its related outcomes. Even though the climate change is one of the results of environmental problems climate change affects and accelerates also environmental pollution. Climate change clearly affects length and effectiveness of the season with forest fire risks and threats the existence of fauna and flora, causes desertification, saltiness and erosion. Students are expected to offer solutions by considering such deteriorations. 


\section{Legal Factors}

In the PESTEL technique, legal factors refer to the civil rights including every details of life (equality, health and safety, equal access opportunities to the services etc.). Therefore, when analysing environment for legal framework on a given subject there is a need to know legal and illegal points. Evaluation of legal framework is a very hard work from the perspective of climate change especially when considered global scale since each country even region has its own set of rules and regulations. In the newly developed versions of PESTEL analysis, ethical factors are also evaluated to analyse the subject. For climate change concept, legal framework can be evaluated together with ethical ones. Therefore, climate change is related to not only legal but also ethical factors. Due to the harmful effects of anthropogenic activities on the global climate and then the biosphere, all the nations and regional initiatives should take urgent ethical and legal measures to prevent these harms from climate change. International laws emerging from treaties or meetings of parties impose obligations to cooperate to protect and improve fundamental human rights that may be lost due to climate change and its effects. Because the threat of climate change on the world is severe and universal, all states and individuals are required to negotiate in good faith for agreements on decisions that affect the climate. Avoiding a severe global catastrophe is an ethical and legal obligation (Ovacik, 2017). In this respect, students are expected to give responses by considering the issues mentioned above.

\section{Results and Disscussion}

Totally 60 workshop participant students in 6 groups were asked to share their opinions about climate change matter considering PESTEL factors in an order and systematic way in convenience with the participatory approaches. It is withdrawn from the general results of the workshop responses from students are categorised into again 6 groups as "political, urban issues, agricultural problems, energy, economic matters and education". In addition, the view as "enacting and implementing legal regulations and incentive laws for the conservation of natural resources and reserves" is presented by all the groups. Results of the factor groups are given as follows.

\section{Political Factors}

As the result of the evaluation, totally 78 different views are obtained by frequency distribution (Table 1). Among the views, distributions of political, urban issues, agricultural problems, energy, economic matters and education are 30\% (23 points), $22 \%$ (17 points), $21 \%$ (16 points), $9 \%$ (7 points), $7 \%$ (5 points) and 8\% (10 points), respectively. 
Determination of University Students' Solutions to Climate Change through PESTEL Analysis in The Sample of Ataturk University

Table1. Proposed measures /solutions for political factors

\begin{tabular}{lc}
\hline Proposed measures /solutions & Frequency \\
\hline $\begin{array}{l}\text { Enacting and implementing legal regulations and incentive laws for the conservation of } \\
\text { natural resources and reserves }\end{array}$ & +++++ \\
Developing policies for enlarging urban green areas & +++ \\
$\begin{array}{l}\text { Enacting and implementing the necessary laws and policies for the protection of forest } \\
\text { and coastal areas }\end{array}$ & +++ \\
$\begin{array}{l}\text { Tax reduction for institutions and organizations struggling with climate change by using } \\
\text { modern production methods }\end{array}$ & +++ \\
$\begin{array}{l}\text { Adopting UN Sustainable Development Goals } \\
\text { Control of the implementation of policies }\end{array}$ & ++ \\
$\begin{array}{l}\text { Compliance with the global protection policies by implementing them throughout the } \\
\text { country }\end{array}$ & + \\
$\begin{array}{l}\text { Developing an incentive and scoring system for the cities realising positive works for } \\
\text { climate change }\end{array}$ & + \\
$\begin{array}{l}\text { Developing institutional policies } \\
\text { Environmentally friendly product stamp - lowering product prices } \\
\text { Activating the carbon exchange }\end{array}$ & + \\
\hline
\end{tabular}

\section{Distribution of views on political factors}

23

Encouraging the activities for urban afforestation and green areas

Reducing greenhouse gas emissions by increasing the use of bicycles and reducing $++$ automobile use

Providing incentives for the recycling of waste materials

The preference of light colors in the exterior colors of the buildings

$++$

Constructing roads from different materials other than asphalt

$+$

Prevention of concreting

Prevention of rapid urbanization

Using smart infrastructure systems

Development of warning systems against flood disaster

Saving the use of water resources

Creating sustainable recycling systems in cities 
Determination of University Students' Solutions to Climate Change through PESTEL Analysis in The Sample of Ataturk University

Table 1 continued

\begin{tabular}{ll}
\hline Distribution of views on urban factors & 17
\end{tabular}

Prohibiting the use of arable lands and pastures for different purposes and ensuring $\quad++++$ control

Reducing foreign dependency in agricultural production by increasing production $\quad+++$ potential with low-interest loan support to farmers

Controlling the use of chemical fertilizers and pesticides $+++$

Encouraging the increase in the use of domestic seed production

Seed breeding policies

Prohibiting the hunting of wild animals

Rural to urban migration can be prevented

The carbon stock can be put into operation in Turkey

Increasing food safety

17

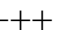

$+$

$+$

$+$

$+$

$+$

$+$

16

Disseminating the use of eco-friendly electric vehicles

$++$

Providing incentives for renewable energy sources

$+$

Development and implementation of solar energy storage road systems

$+$

Establishing policies to minimize the pollution of thermal power plants

Using nuclear power plants

$+$

Reducing over consumption by taking measures for those using water and electricity beyond normal limits

\begin{tabular}{ll}
\hline Distribution of views on energy & 7
\end{tabular}

Raising the amount and types of funds to use for the mitigation and adaptation to climate change

\section{Distribution of views on economy factor}

Increasing the public awareness through activities on environment and measures to be taken against the effects of climate change

Raising the awareness of politicians and decision makers to take required steps

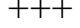

Implementing effective projects related to climate change by institutions and organizations starting at local level Focusing on the classes related to environment at schools

Increasing the public awareness through activities on environment and measures to be taken against the effects of climate change

Distribution of views on education factor

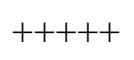

5

$++++$

$+$

$+$

10

Total Frequency 
Determination of University Students' Solutions to Climate Change through PESTEL Analysis in The Sample of Ataturk University

\section{Economic Factors}

Climate change affects social welfare both at present and in the future negatively by slowing down economic development (Fankhauser and Tol, 2005). Evaluation of the responses from 6 different groups shows in Table 2 that totally 75 different views are obtained by frequency distribution. Of the presented opinions by the groups, distributions of the points and percentages for the factor categories are political by $8 \%$ (6 points), urban issues by $21 \%$ (16 points), agricultural problems by $20 \%$ (15 points), energy by $20 \%$ (15 points), economic matters by $20 \%$ (15 points) and education by $13 \%$ ( 8 points).

Table 2. Proposed measures /solutions for economic factors

Proposed measures /solutions

Frequenc

$\mathbf{y}$

Enacting appropriate policies to reduce greenhouse gas emissions $\quad++$

Higher taxes on those using more water and electricity than normal consumption rates +

Promoting companies for the construction of green buildings +

Increasing carbon exchange activities +

$\begin{array}{lc}\text { Distribution of views on political factors } & 6\end{array}$

Providing incentives to use public transport

$++++$

Increasing the type and number of waste treatment plants $\quad+++$

Promoting recycling $\quad+++$

Changing consumption habits to reduce carbon footprint $\quad++$

Producing energy from waste recycling $\quad++$

Increasing the number of waste water treatment facilities +

Increasing green areas in spatial development plans +

\begin{tabular}{ll}
\hline Distribution of views on urban factors & 16
\end{tabular}

Encouraging the use of organic fertilizers instead of chemical fertilizers $\quad+++$

Using new technologies in agricultural production $\quad+++$

Increasing production and reducing foreign dependency by increasing incentives in $\quad+++$ agricultural production

Protection of forests $\quad$ ++

Increasing innovative activities such as vertical agriculture +

Controlling greenhouse activities +

Providing incentives for domestic seed production +

$\begin{array}{lc}\text { Distribution of views on agricultural problems } & 15\end{array}$ 
Determination of University Students' Solutions to Climate Change through PESTEL Analysis in The Sample of Ataturk University

Table 2 continued

Funds for climate change should be increased

$++++$

Grants should be provided to projects and ideas on climate change

$++++$

A special budget should be allocated for green policy

$+++$

Capital supports to recycling factories should be increased

$++$

Educational activities and advertisements should be supported financially for climate and $\quad++$ environmental protection activities

\begin{tabular}{ll}
\hline Distribution of views on economy factor & 15
\end{tabular}

\begin{tabular}{lc}
\hline Increasing the use of renewable energy sources by providing incentives & +++++ \\
Implementation of the laws required to increase the thermal insulation in buildings & +++ \\
Establishing energy efficient management systems & +++ \\
The use of nuclear power plants should be expanded & ++ \\
Increasing incentives for energy production with biogas & + \\
$\begin{array}{l}\text { Contribution to the economy can be achieved by preventing waste and waste in tourism } \\
\text { destination areas. }\end{array}$ & +
\end{tabular}

\begin{tabular}{ll}
\hline Distribution of views on energy & 15
\end{tabular}

Seminars, panels, conferences should be organized to inform citizens about climate change. $\quad++++$

Classes for environmental matters should be made widespread starting from primary $\quad++$ education

Awareness-raising message should be given to people consisting of economists from social $\quad+$ media

Leaders should take pioneering roles in different platforms in order to attract the attention + of the issue to the society and to find common solutions with the parties.

\begin{tabular}{ll}
\hline Distribution of views on education factor & 8 \\
\hline Total Frequency & 75 \\
\hline
\end{tabular}

\section{Social Factors}

Climate change may worsen already hard living conditions of the poor local people in the underdeveloped, politically unstable and badly managed countries and thus leading to violent social conflicts (Smith and Vivekananda, 2007). From the result of the evaluation for social factors, totally 58 different solution proposals are obtained by frequency distribution (Table 3 ). Among the solutions under the factor categories, only political, urban issues and education are evaluated by students and their distributions are $10.3 \%$ (6 points), $13.8 \%$ (8 points) and $75.9 \%$ (44 points), respectively. 
Determination of University Students' Solutions to Climate Change through PESTEL Analysis in The Sample of Ataturk University

Table 3. Proposed measures /solutions for education factors

Proposed measures /solution

Frequency

Imposing deterrent penalties for the destruction of green areas

$+$

$++$

Making the necessary policies to prevent agricultural lands and forests from being urbanised

Ensuring controlled population growth with demographic regulations and population policies

Increasing the number of tourism businesses and their stays with green stars

Distribution of views on political factors

6

Reforestation activities to be carried out in cities should be expanded with the participation ++ of citizens.

Promoting citizens' use of public transport

$++$

Taking necessary measures to prevent migration from rural to urban

$++$

Providing incentives for citizens in waste recycling

$++$

Distribution of views on urban factors

8

Informing citizens through seminars, courses, symposiums and social media

$+++++$

Saving by drawing attention to conscious consumption

$++++$

Dissemination of projects related to climate change

$++++$

Inclusion in projects and programs carried out by NGOs and acting together with decision

$++++$ makers

Creating public service ads and using the media

$++++$

Establishment of international NGOs

3Increasing the number of lessons related to environmental education in schools

Increasing the number of social responsibility projects by providing incentives

Increasing the number of cultural events such as garbage collection and tree planting day and expanding them

Raising awareness of the society about climate change by inductive method

Since the unexpected effects of climate change will affect the psychology of individuals opening centers to support citizens

Researching the possible effects of climate change on society

Pioneers in society should take on advocacy roles on different platforms to attract and produce solutions.

By establishing simulation centers, to show and raise awareness of the disasters that will ++ arise due to climate change.

Distribution of views on education factor

44

Total Frequency

58 
Determination of University Students' Solutions to Climate Change through PESTEL Analysis in The Sample of Ataturk University

\section{Technologic Factors}

It is seen from the responses of the students to technological aspects of climate change that totally 32 views were proposed as the solutions to the impacts of climate change by considering technological advancements. Proposals are given in Table 4 and among them under the factor categories, political factors, agricultural problems, energy and education got the scores and percentages of 13 points and 40.6\%, 7 and 21.8\%, 6 and $18.8 \%$ and 6 and $18.8 \%$, respectively.

Table 4. Proposed measures /solutions for technological factors

\begin{tabular}{lc}
\hline Proposed measures /solutions & Frequency \\
\hline $\begin{array}{l}\text { Recycling the products containing lithium or other toxic substances such as batteries, and } \\
\text { controlling their sales }\end{array}$ & ++++ \\
\hline Reduction of the consumption by producing and using quality products & +++ \\
$\begin{array}{l}\text { Increasing the use of new generation engine technology that uses less energy and fuel } \\
\text { Increasing biodiversity in waters by cleaning seas, lakes and rivers using technological }\end{array}$ & ++ \\
vehicles & + \\
\hline Distribution of views on political factors & $\mathbf{1 3}$ \\
\hline $\begin{array}{l}\text { Saving water consuming less through new technologies in agriculture } \\
\text { Increasing the amount and quality of agricultural products using new technologies in }\end{array}$ & +++ \\
agriculture & ++ \\
Ensuring the use of less fertilizers and pesticides by using new technologies in agriculture & ++ \\
\hline Distribution of views on agricultural problems & $\mathbf{7}$ \\
\hline The widespread use of renewable energy technology in the supply of energy resources & +++ \\
Producing energy from solid waste storage areas & +++ \\
\hline Distribution of views on energy & $\mathbf{6}$ \\
\hline $\begin{array}{l}\text { Raising public awareness by preparing animated films and videos about climate change and } \\
\text { using social media }\end{array}$ & ++++++ \\
\hline Distribution of views on education factor & $\mathbf{6}$ \\
\hline Total Frequency & $\mathbf{3 2}$ \\
\hline
\end{tabular}

\section{Environmental Factors}

Results of several studies in literature focus on green behavior in describing the relationships between specific behaviors such as recycling, using public transport, or purchasing green products (Wu and Chen, 2014; Ofstad et al., 2017). Based on the results of the evaluation for environmental factors, totally 47 different solution proposals are obtained from the students (Table 5). Under the factor categories of political, urban issues, agricultural problems, energy and education, distributions are $14.9 \%$ (7 points), $61.7 \%$ (29 points), $4.3 \%$ ( 2 points), $12.8 \%$ (6 points), $6.3 \%$ (3 points), respectively. 
Determination of University Students' Solutions to Climate Change through PESTEL Analysis in The Sample of Ataturk University

Table 5. Proposed measures /solutions for environmental factors

Proposed measures /solutions

Development of environmental policies by public authority

$+$

Enacting required laws to reduce the degradation of forest and rangeland

Increasing the sanction power of laws for the protection of natural and cultural assets

Preventing from illegal hunting the endangered animals

Not allowing construction that will disturb the ecological balance
$+$

$+$

$+$

$++$

Adoption of an obligation to plant a tree to get identity card for newly born individuals

\begin{tabular}{ll}
\hline Distribution of views on political factors & $\mathbf{7}$
\end{tabular}

The use of green roofs, green buildings and roof gardens in cities should be expanded to $\quad+++++$ increase the amount of green space

Public transport and bicycle use should be increased

Species unique to the region should be preferred in planting studies.

Recycling should be provided with appropriate waste management

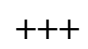

When choosing a place for buildings, a place should be chosen by considering factors such as aspect and sun.

Environment-friendly preference of materials chosen in the construction technique of buildings (such as smart buildings)

Providing incentives to increase the use of electric cars

Attention should be paid to arid landscape works
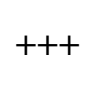

$++$

Intimidating penalties for waste in cities

Touristic facilities and industrial areas should be established at certain distances from the city center.

Proposing compact growth as an urban growth model, system of plans and in cooperation with other sectors

Creating wind corridors passing through the city depending on the prevailing wind direction $\quad+$

Making camp areas instead of hotels and banning vehicle entries in winter sports $\quad+$

\section{Distribution of views on urban factors}

29

Preferring local seeds in agricultural activities and using organic fertilizers instead of chemical fertilizers 
Determination of University Students' Solutions to Climate Change through PESTEL Analysis in The Sample of Ataturk University

Table 5 continued

Distribution of views on agricultural problems 2

Reducing energy consumption and saving energy

$++$

Increasing the use of clean energy resources

The use of waste in energy production

Distribution of views on energy $++$

By ensuring the participation of young people in volunteering activities in NGOs and clubs 6

Environmental projects should be implemented more $++$

Distribution of views on education factor $+$ 3

\section{Legal Factors}

Based on the results of the evaluation for legal factors, totally 35 different solution proposals are obtained from the students (Table 6) all of which are under the factor categories of political factors. The proposals "Implementation of deterrent penalties for the destruction of green areas" and "To enact and enforce conservation laws for the protection of forests and coasts" are also proposed in four of the factor categories above. 
Determination of University Students' Solutions to Climate Change through PESTEL Analysis in The Sample of Ataturk University

Table 6. Proposed measures /solutions for legal factors

\begin{tabular}{lc}
\hline Proposed measures /solutions & Frequency \\
\hline Implementation of deterrent penalties for the destruction of green areas & ++++ \\
To enact and enforce conservation laws for the protection of forests and coasts & ++++ \\
$\begin{array}{l}\text { Monthly electricity and water limits should be determined for people, and those } \\
\text { who exceed this limit should pay tax twice a year. }\end{array}$ & +++ \\
Ensuring the supervision of the enacted laws & +++ \\
Enacting laws to prevent natural areas from opening to development & +++ \\
Increasing environmental and climate laws & +++ \\
Ensuring food safety with laws & +++ \\
Prohibition of hunting wild animals & ++ \\
$\begin{array}{l}\text { Ensuring that managers receive training on climate and providing incentives for } \\
\text { those who receive training }\end{array}$ & ++ \\
$\begin{array}{l}\text { Regions with slums regarding urban development rights should not be given } \\
\text { amnesty }\end{array}$ & ++ \\
Preventing pasture areas from being urbanised & ++ \\
$\begin{array}{l}\text { Adjusting taxes for the industries that create harmful waste to the environment } \\
\text { during the production phase and imposing restrictions }\end{array}$ & + \\
\hline Distribution of views on political factors & $\mathbf{+ +}$ \\
\hline Total Frequency & $\mathbf{3 5}$ \\
\hline
\end{tabular}

\section{Conclusion}

The students $(41.7 \%$ male and $58.3 \%$ female) from Atatürk University Faculties of Architecture and Design; Literature, Economics and Administrative Sciences; Agriculture; Tourism, and Law participated in the workshop program. As a result of the evaluation of the opinions students presented during the workshop, it was determined that female students were more interested in environmental problems and climate change than male students.

Figure 2 and Table 7 show the distribution of students' opinions for factor categories and PESTEL factors. According to the results, the categories received the largest scores are political factors, education, urbanisation and agriculture and others when considering all the PESTEL categories. 
Determination of University Students' Solutions to Climate Change through PESTEL Analysis in The Sample of Ataturk University

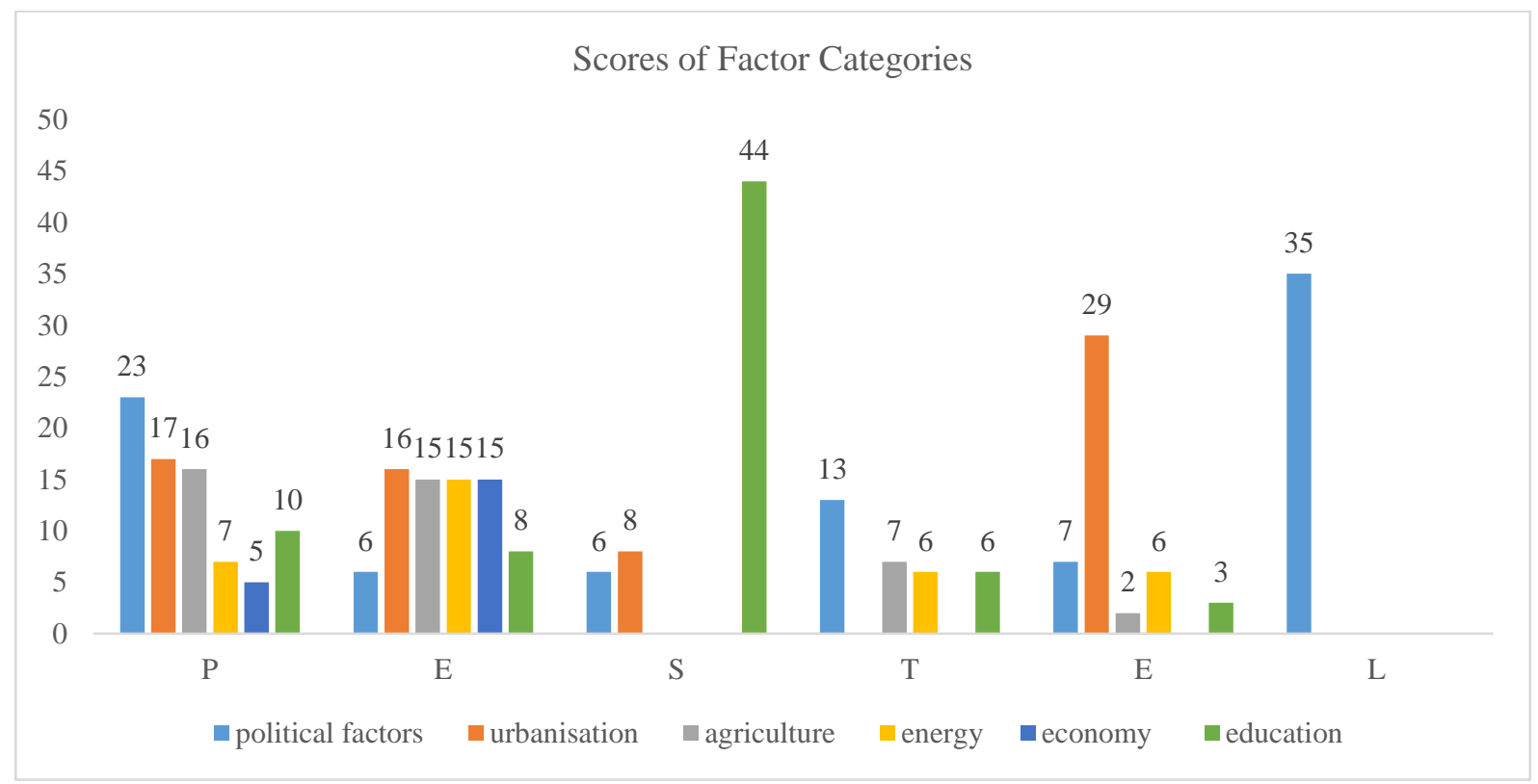

Figure 2. Scores of factor categories

Table 7. Score distribution of factor categories

\begin{tabular}{llllllll}
\hline Factor Categories & $\mathbf{P}$ & $\mathbf{E}$ & $\mathbf{S}$ & $\mathbf{T}$ & $\mathbf{E}$ & $\mathbf{L}$ & Total \\
\hline Political Factors & 23 & 6 & 6 & 13 & 7 & 35 & 90 \\
Urbanisation & 17 & 16 & 8 & & 29 & 70 \\
Agriculture & 16 & 15 & & 7 & 2 & 40 \\
Energy & 7 & 15 & & 6 & 6 & & 34 \\
Economy & 5 & 15 & & & & 3 & 20 \\
Education & 10 & 8 & 44 & 6 & 3 & & 71 \\
Total Frequency & 78 & 75 & 58 & 32 & 47 & 35 & 325 \\
\hline
\end{tabular}

The measures that can be taken jointly in all groups in terms of political, economic, social, technological, environmental and legal aspects to mitigate and adapt to the problems arising from the negative effects of climate change are as follows. 
Determination of University Students' Solutions to Climate Change through PESTEL Analysis in The Sample of Ataturk University

\section{Political measures}

- Enacting and implementing legal regulations and incentive laws for the conservation attempts of natural resources and reserves

- Encouraging the activities for urban afforestation and the constitution of forests and green fields

- Prohibiting the use of arable lands and pastures for different purposes and ensuring control

- Raising the public environmental awareness and measures to be taken against the effects of climate change

\section{Economic measures}

- Establishing and implementing appropriate policies to reduce greenhouse gas emissions

- Providing incentives to use public transport

- Encouraging the use of organic fertilizers instead of chemical ones

- Using new technologies in agricultural production

- Increasing production and reducing foreign dependency by increasing incentives in agricultural production

- Increasing the amount and types of funds related to climate change

- Providing grants to projects and ideas on climate change

- Organising seminars, panels, conferences to inform citizens about climate change.

\section{Social measures}

- Controlling the population growth with demographic regulations and population policies

- Informing citizens through seminars, courses, symposiums and social media

- Saving everything by drawing attention to conscious consumption

- Dissemination of project results related to climate change

- Inclusion in projects and programs carried out by NGOs and acting together with decisionmakers

- Creating public service ads and using the media

These opinions are common for 4th and 5th groups while other two groups presented three additional ideas as "It may be a useful action to open psychological support centers for citizens to protect their mental health since the unexpected effects of climate change is expected to be effective on the psychology of individuals". The second measure idea is "to investigate the effects of climate change on society" and the third one is "To increase public awareness towards climate change by establishing simulation centres to show the locals disasters resulting from climate. 
Determination of University Students' Solutions to Climate Change through PESTEL Analysis in The Sample of Ataturk University

\section{Environmental measures}

- Increasing the use of green roofs, green buildings and roof gardens in cities and the amount of green spaces

- Preference of environment-friendly materials in the construction technique of buildings (such as smart buildings)

- Proposing compact growth as an urban growth model, preparing plans in a system with the participation and cooperation with other sectors

\section{Technologic measures}

- Raising public awareness by preparing animated films and videos about climate change and using social media,

- Recycling the products containing lithium or other toxic substances such as batteries, and controlling their sales

- Ensuring the use of less fertilizers and pesticides, saving water and increasing production by using new technologies in agriculture

- The widespread use of renewable energy technology in the supply of energy resources

- Producing energy from solid waste storage areas

\section{Legal measures}

- Imposing deterrent penalties for the destruction of green areas

- Enacting and implementing the necessary laws and policies for the protection of forest and coastal areas

Several studies in literature support the results obtained from the workshop in the present study (Zsoka et al. 2013; Grace and Ratcliffe 2002; Monroe and Krasny,2016; Toomey et al., 2017; Candamio et al, 2018; Ardoin et al, 2020). Anderson (2012) made a comprehensive and multidisciplinary definition for "Climate Change Education for Sustainable Development" and stated that this education type should involve skills and content knowledge to develop critical thinking, problem solving and collaboration, reduction of risks from disasters, preparedness. In a study conducted to measure the environmental awareness of university students, it was found that $75.5 \%$ of the students followed environmental issues on the internet and television (Erdal et al., 2013). Yildiz et al., (2011) identified the awareness and sensibility levels of campus people about environmental problems in Erzurum over 350 volunteers and $64.4 \%$ of the campus people were aware of the environmental problems. The necessity of a multidisciplinary education is emphasized in order to achieve sustainable development goals in higher education (Lozano et al., 2013). For this purpose, multidisciplinary training activities include different types of information to investigate, analyze and find solutions to problems. Therefore, activities with multi stakeholders are considered to be highly important for social and environmental matters (Gaziulusoy and Boyle, 2013). Thus, interdisciplinary activities are thought to increase sustainability at universities by revising their missions and reforming their research programs, curriculum and life cycles at campuses, and improving collaboration with other public institutions (Waheed et al., 2011). In order to improve the sustainability indicators in higher education, related 
Determination of University Students' Solutions to Climate Change through PESTEL Analysis in The Sample of Ataturk University

activities should be planned by reorienting education, research and social benefits programs (Wals, 2014; Lambrechts et al., 2013). When the responses of the working groups for the measures to be taken regarding the reduction of emissions and adaptation to climate change were evaluated, it was evaluated that all groups made very important suggestions in political, economic, social, technological, environmental and legal terms. Such workshops should be disseminated among different professional disciplines, allowing new ideas and suggestions to emerge and shared with the public.

\section{Acknowledgement}

This study is the evaluation of the results of the workshop organisation held in the scope of "University Youth is Discussing Climate Change at the Peak of Anatolia" supported by EU Program (sub-grant Env.Net).

\section{References}

Aguilar, F. J. 1967. Scanning the Business Environment, Macmillan, New York, NY.

Anderson A., 2012. Climate Change Education for Mitigation and Adaptation. UNESCO Special Section on the ESD Response to the Three Rio Conventions. Vol 6(2): 191-206 $10.1177 / 0973408212475199$.

Ardoin, N. M., Bowers,A. W., Gaillard,E. 2020. Environmental Education Outcomes for Conservation: A systematic review. Biological Conservation, Volume 241, 108224.

Azeiteiro, U. M., Bacelar-Nicolau, P., Caetano, F. J. P., Caeiro, S., 2015. Education for Sustainable Development Through e-Learning in Higher Education: Experiences from Portugal. Journal of Clean Production, 106, 308e319. http://dx.doi.org/10.1016/ j.jclepro.2014.11.056.

Başoğlu, B., 2014. Küresel İklim Değişikliğinin Ekonomik Etkileri. KTÜ Sosyal Bilimler Enstitüsü Dergisi, Sayı 7, 2014, s.178.

Bakoğlu R., Yıldız, M. L. 2018. Üniversitelerde Strateji Geliştirme Sürecinde Uygulamalı Durum Analizleri. Yüksekögretim Dergisi, 8(1):124.

Candamio, L, V., Corti, I, N., Alvarez, M.T.G. 2018. The importance of Environmental Education in The Determinants of Green Behavior: A Meta-Analysis Approach. Journal of Cleaner Production, 170, 1565e1578.

Dare, C. 2006. The UK Tour-Operating Industry: A Competitive Analysis. Journal of Vacation Marketing, 6(4), 357-367.

Demirbilek, M. 2016. “Çevre, Çevre Mültecileri ve Çevreci Sosyal Hizmet”. International Journal of Social Sciences and Education Research, Vol.2, No.3, ss.905 91.

Demirtaş, I.2013. Enerji Teknolojileri Ar-Ge Politikaları: Oecd Ülke Deneyimleri Ve Türkiye Karşılaştırması. Bilgi Ekonomisi ve Yönetimi Dergisi, 2013 Cilt: VIII Sayı: II.

Erdal, H., Erdal, G., Yücel, M. 2013. Üniversite Öğrencilerinin Çevre Bilinç Düzeyi Araştırması: Gazi Osman Paşa Üniversitesi Örneği. Gazi Osman Paşa Üniversitesi Bilimsel Araştırma Dergisi, 4, 57-65. 
Determination of University Students' Solutions to Climate Change through PESTEL Analysis in The Sample of Ataturk University

Ediger, V. Ş. 2008. Küresel İklim Değişikliğinin Uluslararası İlişkiler Boyutu ve Türkiye'nin Politikaları. Mülkiye Cilt: XXXII, Sayı259.

Ekşi, N. (2016), "İklim Mültecileri”, Göç Araştırmaları Dergisi, C.2, S.2, ss.10-58. European Commission 2000. Summary Record of Meeting: ECCP Working Group 1 https://ec.europa.eu/clima/sites/default/files/eccp/first/docs/wg1_minutes_en.pdf.

Fankhauser, S., Tol, R. S. J. 2005. "On Climate Change and Economic Growth." Resource and Energy Economics, 27: 1-17.

Guerra, J. B. S. O. A., Garcia, J, S, B., Heerdt, M., Berchin,I, I. A. 2018. Proposal of a Balanced Scorecard for an Environmental Education Program at Universities. Journal of Cleaner Production, Volume 172, Pages 1674-1690.

Gaziulusoy, A. I., Boyle, C., 2013. Proposing a Heuristic Reflective Tool for Reviewing Literature in Transdisciplinary Research for Sustainability. Journal of Cleaner Production, 48, 139e147. http://dx.doi.org/10.1016/j.jclepro.2012.04.013.

Grace, M. M., \& Ratcliffe, M. 2002. The Science and Values That Young People Draw Upon To Make Decision About Biological Conservation İssues. International Journal of Science Education, 24(11), 1157-1169.

Grady-Benson, J., \& Sarathy, B. 2015. Fossil Fuel Divestment in US Higher Education: Student Led Organising for Climate Justice. Local Environment, 21(6), 661-681.

Houghton, J. T., Ding, Y., Griggs, D. J., Noguer, M., Linden, P.J., Dai, X., Maskell, K., Johnson, C.A. 2001. Climate Change 2001: The Scientific Basis. Contribution of Working Group I to the Third Assessment Report of the Intergovernmental Panel on Climate Change Published for the Intergovernmental Panel on Climate Change.

IPCC, 2007: Summary for Policymakers. In: Climate Change 2007: Impacts, Adaptation and Vulnerability. Contribution of Working Group II to the Fourth Assessment Report of the Intergovernmental Panel on Climate Change, M.L. Parry, O.F. Canziani, J.P. Palutikof, P.J. van der Linden and C.E. Hanson, Eds., Cambridge University Press, Cambridge, UK, 7-22.

IPCC 2001. Summary For Policymakers Climate Change 2001: Impacts, Adaptation, And Vulnerability Climate Change 2001: Impacts, Adaptation, and Vulnerability United Nations Framework Convention on Climate Change https://unfccc.int/files/press/backgrounders/application/pdf/press_factsh_science.pdf. Katko, T. S. 2006. Road Safety Fatalities, Management, and Policy in Finland, 1970-2003. Public Works Management \& Policy, 11(2), 126-138. http://dx.doi.org/10.1177/1087724X06294066.

Li, M., Wang, Q., 2017. Will Technology Advances Alleviate Climate Change? Dual Effects of Technology Change on Aggregate Carbon Dioxide Emissions. Energy for Sustainable Development, 41, 61-68.

Lambrechts, W., Mula, I., Ceulemans, K., Molderez, I., Gaeremynck, V., 2013. The İntegration of Competences for Sustainable Development in Higher Education: An Analysis Of Bachelor Programs İn Management. Journal of Cleaner Production, 48, 65e73. http://dx.doi.org/10.1016/j.jclepro.2011.12.034 (Accessed 23 February 2016). 
Determination of University Students' Solutions to Climate Change through PESTEL Analysis in The Sample of Ataturk University

Lozano, R., Lukman, R., Lozano, F.J., Huisingh, D., Lambrechts, W., 2013b. Declarations for Sustainability in Higher Education: Becoming Better Leaders, Throug Addressing the University System. Journal of Cleaner Production, 48, 10e19. http://dx.doi.org/ 10.1016/j.jclepro.2011.10.006.

Meyer, A., 2015. Does Education İncrease Pro-Environmental Behavior? Evidence from Europe. Ecol. Econ. 116, 108e121. http://dx.doi.org/10.1016/ j.ecolecon.2015.04.018. Monroe, M.C., Krasny M.E. 2016. Across the Spectrum: Resources for Environmental Education (3rd ed.), North American Association for Environmental Education, Washington, DC.

Monroe, M.C., Plate, R.R., Oxarart, A., Bowers, A., Chaves, W.A., 2017. Identifying Effective Climate Change Education Strategies: A Systematic Review of the Research. Environment Education Research, 1-22. https://doi.org/10.1080/13504622.2017.1360842.

Neubauer, J., Wood, E. 2014. Thru-Life İmpacts of Driver Aggression, Climate, Cabin Thermal Management, and Battery Thermal Management on Battery Electric Vehicle Utility. Journal of Power Sources, Volume 259, 1 August 2014, Pages 262-275.

Ofstad, S.P., Tobolova, M., Nayum, A., Klockner, C.A., 2017. Understanding the Mechanisms Behind Changing People's Recycling Behavior at Work by Applying a Comprehensive Action Determination Model. Sustainable, 9 (2), 204.

Oktay, N. 2006. PEST Analizi. Türkiye Sanayi Sevk ve İdare Enstitüsü, Haziran, tepav.org.tr Ovacık, G. Küresel İklim Değişikliği Yükümlülükleri Hakkında Oslo İlkeleri ve İklim Mücadelesinde Uluslararası ve Yabancı Mahkeme Kararları. Ekoloji Kolektifi Derneği Basım Tarihi: Ocak, 2017, 1. Baskı Editör: ISBN: 978-605-83799-9-2.

Richards, J.V. 2006. Education for Librarianship in the Russian Far East: An Update on the Vladivostok State University of Economics and Services. Journal of Education for Library and Information Science, Vol. 47, No. 2.

Shilei, Lv., Yong,Wu. 2009. Target-Oriented Obstacle Analysis By PESTEL Modeling of Energy Efficiency Retrofit for Existing Residential Buildings in China's Northern Heating Region. Energy Policy, Volume 37, Issue 6, June 2009, Pages 2098-2101.

Smith, D., Vivekananda, J. 2007. "A Climate of Conflict: The Link between Climate Change, Peace and War", International Alert, November.

Su, H.N., Moaniba, I.M., 2017. Does İnnovation Respond to Climate Change? Empirical Evidence from Patents and Greenhouse Gas Emissions. Technological Forecasting Social Change, 122, 49-62

Toomey, A.H., Knight, A.T., Barlow, J., 2017. Navigating the Space Between Research Andimplementation in Conservation. Conservation Letters, 10, 619-625.

TURKSTAT 2021. https://data.tuik.gov.tr/Bulten/Index?p=Adrese-Dayal\%C4\%B1N\%C3\%BCfus-Kay\%C4\%B1t-Sistemi-Sonu\%C3\%A7lar\%C4\%B1-2020-37210\&dil=1.

Waheed, B., Khan, F., Veitch, B., Hawboldt, K. (2011b). "Uncertainty-based Quantitative Assessment of Sustainability for Higher Education İnstitutions". Journal of Cleaner Production, Vol. 19 No. 7, pp. 720-32. 
Determination of University Students' Solutions to Climate Change through PESTEL Analysis in The Sample of Ataturk University

Wals, A.E.J., 2014. Sustainability in Higher Education in The Context of the UN DESD: A Review of Learning and İnstitutionalization Processes. Journal of Cleaner Production, 62, 8e15. http://dx.doi.org/10.1016/j.jclepro.2013.06.007.

Wu, S.-I., Chen, J.-Y., 2014. A Model of Green Consumption Behavior Constructed by the Theory of Planned Behavior. Interantional Journal Marketing Studies, 6 (5), 119e132.

Yildiz ND., Yilmaz H., Demir M., Toy S. 2011. Effects of Personal Characteristics on Environmental Awareness; A Questionnaire Survey With University Campus People in a Developing Country, Turkey. Scientific Research and Essays, 6 (2): 332 - 340.

Yüksel İ. 2012. Developing a Multi-Criteria Decision Making Model for PESTEL Analysis.

International Journal of Business and Management, Vol. 7, No. 24.

Zsoka, A., Sezerenyi, Z. M. Szechy, A., Kocsis, T., 2013. Greening Due to Environmental Education? Environmental Knowledge, Attitudes, Consumer Behavior and Everyday Proenvironmental Activities of Hungarian High School and University Students. Journal of Cleaner Production, Volume 48, June 2013, Pages 126-138 